\title{
Delineating the dynamics of growth and instability of different Non-Timber Forest Products (NTFP's) in Gujarat
}

\author{
Anjali S. Chaudhari ${ }^{1}$, K.A. Khunt ${ }^{2}$, Viralkumar P. Chaudhari* and C.P. Chetariya ${ }^{3}$ \\ PGIABM, Junagadh Agricultural University, Junagadh (Gujarat) India \\ (Email:vira16929@gmail.com)
}

\begin{abstract}
The importance of Non-Timber Forest Products (NTFPs) and its contribution to rural livelihoods and alleviating rural poverty is well known in Gujarat and emerging as the source of income for the rural poor. Therefore, promotion of Non-Timber Forest Products (NTFP) species, therefore, the present study aimed at to examine the growth rates and instability of different forest products. The secondary data on quantity and value of different wood and non-wood products from the year 1996-97 to 2017-18 were compiled from published sources. The results revealed that quantity of Mahuda flowers and Honey increased significantly while majority of NTFPs found to be decreased but it is statistically non-significant during overall period. Instability indices of both quantity as well as value of NTFPs found to be higher during overall period. The quantity of teak timber significantly increased in Valsad circle but it significantly decreased in Ahmedabad circle, while change in value found to be nonsignificant in all circles during overall period because of irregular and timely non-availability of NTFPs.
\end{abstract}

Key Words : Growth, Non-timber forest products

View Point Article : Chaudhari, Anjali S., Khunt, K.A., Chaudhari, Viralkumar P. and Chetariya, C.P. (2021). Delineating the dynamics of growth and instability of different Non-Timber Forest Products (NTFP's) in Gujarat. Internat. J. agric. Sci., 17 (2) : 135-140, DOI:10.15740/ HAS/IJAS/17.2/135-140 Copyright@2021: Hind Agri-Horticultural Society.

Article History : Received : 20-02-2021; Revised : 25-02-2021 Accepted : 13-03-2021

\footnotetext{
*Author for correspondence:

${ }^{1}$ Department of Agricultural Economics, NMCA, Navsari Agricultural University, Navsari (Gujarat) India

${ }^{2}$ College of Agriculture, Junagadh Agricultural University, Junagadh (Gujarat)

${ }^{3}$ A.S.C.O., G.S.S.C.A., Junagadh (Gujarat) India
} 